\title{
THE MAKING OF A FEMALE MARXIST: E.D. KUSKOVA'S CONVERSION TO RUSSIAN SOCIAL DEMOCRACY*
}

SUMMARY: Historians have traditionally overlooked the role of women in Russian Social Democracy. This article, based on archival as well as published sources, examines the radicalization of E.D. Kuskova (1860-1958), a long neglected participant in the Russian Marxist movement during its formative years.

Kuskova was attracted to radicalism by its promise of a fulfilling life of service to society, and as an escape from the traditional, confining roles for women in prerevolutionary Russia. She came to Social Democracy after concluding that it provided a more satisfactory Weltanschauung and a more accurate diagnosis of Russia's socioeconomic ills than did its ideological alternatives.

For the Russian revolutionary movement, the 1880 s and early 1890 s were critical years. The political reaction that set in during the reign of Alexander III (1881-1894) forced not only a reorganization of the movement but also a rethinking of revolutionary goals and strategies. It was in these circumstances that Marxism emerged to vie with the older Populist ideology for the loyalty of Russia's oppositional elements, and for the leadership of the country's nascent labor movement. The success of Russian Social Democracy, crowned as it was by the Bolshevik Revolution in October 1917, assured the men who participated in the early Marxist efforts a prominent place in the historiography of the revolutionary movement. But what of Russia's first women Marxists?

Although significant numbers of young women joined the Social Democratic movement in the 1880 s and early 1890 s, they have remained obscure and ephemeral historical figures. In contrast to their male counterparts, these first female Marxists have gone virtually unnoticed by scholars, who have cared little about women's participation in Russian Social Democracy. ${ }^{1}$ Much has still to be learned, therefore, about Russia's earliest women

* Research for this article was originally undertaken in connection with my dissertation, "E.D. Kuskova: A Political Biography of a Russian Democrat. Part 1: 1869-1905" (Ph.D., The Pennsylvania State University, 1981).

${ }^{1}$ Western historiography has produced only three studies of women who entered the ranks of Russian Social Democracy in this period: Robert $\mathrm{H}$. McNeal, Bride of the Revolution: Krupskaia and Lenin (Ann Arbor, MI, 1972); Jay Bergman, Vera Zasulich: A Biography (Stanford, CA, 1983); and Beate Fieseler, "Women in Russian Social Democracy, 1890-1917: The Making of Women Social Democrats", unpublished paper presented to the Conference on Women in the History of the Russian Empire, Akron, 
Marxists, beginning with the process of their radicalization and entrance into the Social Democratic movement. Yet, until historians attend to these issues, our understanding of Russian Social Democracy in its formative period - indeed, of the entire revolutionary movement in these critical years - will be incomplete.

The present study, an investigation of the early political biography of E.D. Kuskova (1869-1958), is an attempt to rescue one of Russia's first female Marxists from obscurity. An important but long-neglected radical, Kuskova has been described by a contemporary as "one of the pioneers of the Russian Social Democratic movement, even one of the founders of the Social Democratic party in Russia". ${ }^{2}$ Thus, an examination of her political socialization and radicalization should serve to shed light on such important issues as: (1) the circumstances that led Russia's first female Marxists to forsake traditional, socially sanctioned roles for involvement in radical politics; (2) the attraction that Marxism, in particular, held for these women; and (3) the nature of their commitment to Social Democracy. This, in turn, may help to point the way for further inquiry into women's participation in the Russian Social Democratic movement during its formative years.

In contrast to the majority of women involved in Russian Marxism in the prerevolutionary period, Kuskova has left a detailed account of her early political thought and activity. Her memoirs and reminiscences, although far from complete and sometimes contradictory in their details, yield a great deal of information about her political socialization and radicalization. ${ }^{3}$

$\mathrm{OH}$, August 1988. On the general neglect of women in Russian Social Democracy in the prerevolutionary period, see Fieseler, "Women in Russian Social Democracy", pp. 1-2. ${ }_{2}^{2}$ G.Ia. Aronson, "E.D. Kuskova. Portret obshchestvennogo deiatelia", Novyi zhurnal, XXXVII (1954), p. 237. It is indicative of historians' lack of interest in Russia's first women Marxists that the most extensive attention to Kuskova's early political thought and activity is that provided in Shmuel Galai, The Liberation Movement in Russia (Cambridge, 1973), pp. 61-63, 65, 71, 74.

${ }^{3}$ The principal source is Kuskova's memoirs, "Davno minuvshee", which appeared in Novyi zhurnal between 1955 and her death in 1958; these cover the first three decades of her life. Additional reminiscences about this period are contained in her "Tragediia Maksima Gor'kogo", Novyi zhurnal, XXXVII (1954), pp. 224-245, and "Nadpol'e i podpol'e marksizma", Novoe russkoe slovo, 24 July 1954. Unpublished reminiscences are found in Kuskova's correspondence with three emigré friends, written between 1949 and 1957 and preserved in the L.O. Dan Archive of the Internationaal Instituut voor Sociale Geschiedenis, Amsterdam [hereafter, IISG], and in the V.A. Maklakov and N.V. Volsky collections of the Hoover Institution on War, Revolution and Peace, Stanford, CA [hereafter, HIWRP].

These recollections, written after more than forty years, contain numerous inconsistencies in points of detail, and especially dating. This reflects not only the vagaries of time and memory but also a certain carelessness on Kuskova's part. Yet, the over-all chronology and her general reconstruction of events is consistent throughout her writings and is often verifiable from other sources. 
Combined with contemporary police reports ${ }^{4}$ and the memoirs and reminiscences of other radicals, ${ }^{5}$ these sources provide ample evidence with which to reconstruct the process that culminated in her conversion to Social Democracy.

Ekaterina Dmitrievna Kuskova was born in 1869 in the southern Ural provincial capital of Ufa to Ludmila Mikhailovna Esipova and Dmitrii Petrovich Esipov. ${ }^{6}$ There was little in her family background or childhood experiences to predict a future of political radicalism for her. Her parents appear to have been largely apolitical; in her memoirs she reports only a single family episode with political overtones. As for her early education, it was designed, like all formal education in Russia at the time, to insulate students as much as possible from all radical influences.

The Esipovs' economic situation appears to have been comfortable enough throughout Kuskova's early childhood. Her father's job as an excise tax collector (aktsiznyi chinovnik) required the family to relocate several times before settling in 1879 in Saratov, the provincial capital on the lower Volga. ${ }^{7}$ It was here that Kuskova would receive most of her early formal education.

Within two years after the move to Saratov, Kuskova's parents separated. The immediate cause of the separation would not be especially noteworthy except that Kuskova's account of it provides the only glimpse of her parents' political views. Apparently, her father had hired a kursistka ${ }^{8}$ to

\footnotetext{
${ }^{4}$ Some of these have been published in Obzor vazhneishikh dozanii, proizvodivshikhsia $v$ zhandarmskikh upravleniiakh Imperii, po gosudarstvennym prestupleniiam, XVII ([St. Petersburg], n.d.) and L.P. Men'shchikov, Okhrana i revoliutsiia, 3 vols (Moscow, 1925-1932). A generous colleague has provided detailed notes on police files - some of them inaccessible to Western scholars - preserved in Tsentral'nyi gosudarstvennyi arkhiv Oktiabr'skoi revoliutsii, Moscow [hereafter, TsGAOR] and in Gosudarstvennyi arkhiv saratovskoi oblasti, Saratov [hereafter, GASO].

${ }^{5}$ Most important among these are V.M. Chernov, Zapiski sotsialista revolutionera (Berlin, 1922); S.I. Mitskevich (ed.), Na zare rabochego dvizheniia v Moskve (Moscow, 1932), and Na grani dvukh epokh. Ot narodnichestva $k$ marksizmu (Moscow, 1937).

${ }^{6}$ Kuskova, "Davno minuvshee", XXXXIII (1955), pp. 96, 113, 115; and G.Ia. Aronson, "K 80-tiletiiu. E.D. Kuskovoi", Sotsialisticheskii vestnik, XII, no. 627 (1949), p. 223. I have adopted the name "Kuskova" throughout for the sake of convenience and to avoid confusion, since her surname changed twice in the period under consideration. In fact, she did not become Kuskova until her second marriage in 1893.

${ }^{7}$ Kuskova, "Davno minuvhsee", XXXXIII, pp. 96-112. The surname Esipov suggests that Kuskova's father probably belonged to one of Russia's oldest and most prestigious untitled noble families, albeit a branch that no longer retained any wealth. Entsiklopedicheskii slovar', 43 vols (St. Petersburg, 1893-1907), XIa (1894), p. 648, s.v. "Esipovy". 8 That is, a student in the "women's higher courses" (vysshie zhenskie kursy), initiated at the beginning of the 1870 s as private, non-degree granting institutions of higher education for women. See Entsiklopedicheskii slovar' XX (1894), pp. 870-873 s.v. 'Zhenskoe obrazovanie"; and Ruth A.F. Dudgeon, "Women and Higher Education in Russia, 1855-1905" (Ph.D., George Washington University, 1975), pp. 130-131.
} 
provide music lessons for his two daughters. But the presence of this young woman, with her closely cropped student's hair, provoked angry assertions from Esipova that all kursistki were nihilist "progressives". Kuskova remembers, too, how the young woman sometimes brought Esipov books and often had extended conversations with him, "the meaning of which I did not then grasp. Words flashed - 'society', 'tendencies', 'struggle'. Sometimes they both got excited, argued ... [sic] If at this time Mother came, the conversation quickly died out."9 Motivated by extreme jealousy, but also perhaps by fear that her daughters might be infected by the revolutionary contagion, Esipova left her husband, taking the two children with her. ${ }^{10}$ While not greatly revealing, this incident does suggest that, to the limited extent that Kuskova's mother thought about and understood the revolutionary movement, she was very disapproving of it. Esipov, in contrast, seems to have had some sympathy for the movement, or at least for the aspirations of the revolutionaries.

Following the separation from her husband, Esipova found work as manager of a local almshouse. ${ }^{11}$ These changed circumstances would soon affect Kuskova's life profoundly. For the time being, however, she remained happily preoccupied with school. The curriculum of the Saratov gymnasium, like that of all gymnasia in the period, was the "classical curriculum" of the Minister of Education, Count D.A. Tolstoi. The practical application of the "Tolstoian system" in the girls' schools differed slightly from that in the boys' since it was intended to prepare Russia's young women for their future roles as wives and mothers or as primary school teachers. ${ }^{12}$ Echoing the view of a generation of Russian radicals who correctly perceived this system as an attempt to prevent students from having any contact with social or political issues, Kuskova writes in her memoirs: "Here we studied 'without practical aims', without experiments and natural science in order 'not to sink into materialism'."13

The gymnasium was not entirely immune to radical influences, however.

${ }^{9}$ Kuskova, "Davno minuvshee", XXXXIII, p. 112. Also, p. 111.

${ }^{10}$ Ibid., pp. 116-117. Also see ibid., XXXXIV (1956), p. 124, and Kuskova to N.V. Vol'skii, 10 November 1955, HIWRP, Volsky Collection, box 5.

${ }^{11}$ Kuskova, "Davno minuvshee", XXXXIV, pp. 124, 129-130, 138, and XXXXIII, p. 117.

${ }_{12}$ Ibid., XXXXV (1956), p. 159. The typical curriculum for girls' gymnasia included the following subjects required during a seven year period: religion, Russian, French, German, mathematics, history, geography, physics, drawing, needlework, gymnastics, and choir. S. Satina, Education of Women in Pre-revolutionary Russia, trans. A.F. Poustchine (New York, 1966), p. 45. It is worth noting that, even as late as 1894, only one percent of all Russian girls attended school (as compared with approximately four percent of all boys). Richard Stites, The Women's Liberation Movement in Russia. Feminism, Nihilism and Bolshevism, 1860-1930 (Princeton, NJ, 1978), p. 166.

${ }^{13}$ Kuskova, "Davno minuvshee", XXXXV, p. 159. 
In the spring of 1884 , Kuskova encountered a young teacher named Orlov who introduced his pupils to the social aspects of Pushkin's poetry. Orlov's "political" discussions quickly came to the attention of the school authorities and the governor of Saratov who confiscated notebooks in which Kuskova and her classmates had written of Pushkin's "contempt for the people". Orlov was immediately arrested and sent into exile. This was Kuskova's first experience with the arbitrariness and severity of the Russian police system; she was duly impressed. ${ }^{14}$

Shortly after Orlov's arrest, Kuskova was expelled from the gymnasium. Her "seditious" essay was only partly responsible; frequent absenteeism was also to blame. By this time, tuberculosis had made Kuskova's mother an invalid, and the burden of housekeeping and caring for her younger sister had fallen to Kuskova alone. ${ }^{15}$ Moreover, although the family was in dire financial straits, Esipova rebuffed all her husband's efforts to help them. Consequently, there was no longer sufficient money to purchase textbooks and Kuskova had precious little time to attend to her studying. As her mother's health had deteriorated, Kuskova had also been obliged to assist in the running of the almshouse. In these circumstances her expulsion from the gymnasium in the spring of 1884 was not altogether unwelcome. ${ }^{16}$

More and more during this period, Kuskova took refuge in books. She also found distraction and companionship with several other gymnasium students at the almshouse and with the doctor of the establishment. The latter brought the youngsters books (including Ostrovskii, Turgenev, Pisemskii, Gogol, Pushkin, and Shakespeare), and spent a good deal of time talking with them about various intellectual subjects. ${ }^{17}$

Towards the end of 1884, Esipova died, leaving Kuskova alone to look after her sister. For some months Kuskova continued as sole manager of the almshouse, an all-consuming and exhausting task. In spite of everything, however, she resumed her schooling, matriculating as an external student. In the spring of 1885 , at the age of fifteen, she graduated from the Saratov gymnasium with highest distinction. ${ }^{18}$

The two principal professions available to Kuskova as a single, gymnasium educated woman - those of teacher and governess - held no attraction for her. Indeed, a career as a governess seemed to her a fate worse than death. Consequently, Kuskova now took a job preparing graphs for the local branch of the railroad administration, thereby avoiding more conven-

${ }^{14}$ Ibid., pp. 161-162, 166-167. Also see XXXXIV, pp. 136-137.

is Ibid., XXXXV, pp. 163, 166-167, and XXXXIV, p. 138.

${ }^{16}$ Ibid., XXXXIV, pp. 124, 129-130, 138, XXXXIII, p. 117, and XXXXV, p. 167.

${ }^{17}$ Ibid., XXXXIII, p. 118, and XXXXIV, p. 136. Also see, XXXXIV, pp. 125, 131, 134.

${ }^{18}$ Ibid., XXXXIV, pp. 140-142, and XXXXV, pp. 162, 169. The date of her graduation is confirmed by police files. TsGAOR, f. 102, 3d-vo, 1894, d. 19, 1. 2 . 
tional women's work. ${ }^{19}$ Although overjoyed with her new found independence, she remained at this job only a short while. Her friendship with her former chemistry and physics teacher, I.P. Iuvenaliev, had deepened since her graduation, and they were married during the winter of 1885-86. She was sixteen and he thirty-two. ${ }^{20}$ This companionate marriage, based as it was on mutual respect and mutual need, provided Kuskova with the personal happiness and economic security she had been without for so long. Yet it did not confine her to a life of domesticity. This marriage also provided her entree into the world of the Saratov radical intelligentsia where the seeds of political awareness planted in her adolescence would begin to take root.

By the mid-1880s, Saratov had a well-established radical tradition dating back more than three decades. This was an area with a particularly large proportion of intelligentsia and small merchants among whom radical ideas spread quickly. In addition, Saratov was connected by railroad with the heart of the country and for some time had also been a center for political exiles. All of these factors combined to make the community a congenial setting for revolutionary propaganda and agitation. ${ }^{21}$

Beginning with the renowned writer and socialist, N.G. Chernyshevskii, Saratov radicals had contributed importantly to the birth of the Populist ideology, based on the idea that socialism would grow out of the peasant commune. In the 1870s, Saratov had been one of the largest centers of the Populist movement in the country. During that decade, the movement 'to the people' had gained considerable momentum in the area and, following the formation of the illegal organization Land and Liberty (Zemlia $i$ volia) in 1878, such important, well-known figures as the future Marxist leaders G.V. Plekhanov and V.I. Zasulich were among those conducting revolutionary propaganda in Saratov province. 22

At the beginning of the 1880s, a major circle of the People's Will (Narodnaia volia) had been located in Saratov. Now, in the second half of the decade, revolutionism had diminished significantly due to increased police activity, the emigration of many revolutionaries and the general disillusionment that prevailed following the destruction of the People's Will. Populism continued, however, to be the dominant political trend among local radicals. Social Democracy, which already represented a major ideological

${ }^{19}$ Kuskova, "Davno minuvshee", XXXXV, pp. 174-177.

${ }^{20}$ Ibid., XXXXV, pp. 176-177, 180.

${ }^{21}$ On Saratov as a place of exile, see G. Ul'ianov, "Vospominaniia o M.A. Natansone", Katorga i ssylka, no. 4/89 (1932), pp. 62-63; and V.V. Shirokova, Partiia "Narodnogo prava". Iz istorii osvoboditel'nogo dvizheniia 90-kh godov XIX veka (Saratov, 1972), pp. 33-35.

${ }_{22}$ On the Saratov revolutionary movement in the 1870 s, see V.V. Shirokova, Ocherki istorii obshchestvennogo dvizheniia v saratovskoi gubernii v poreformennyi period (Saratov, 1976), pp. 15, 17-21. 
and organizational alternative elsewhere in the country, had yet to gain a hold in Saratov. At the same time, such liberal sentiment as existed there was still confined largely to literary circles and the zemstvos (district and provincial organizations of local self-government). In this period, so often referred to disparagingly as the era of "small deeds", Saratov Populists and liberals directed most of their efforts towards improving the economic and cultural circumstances of the Russian people. ${ }^{23}$

In this setting, principally in the so-called circles of self-education (khruzhki samoobrazovaniia), Kuskova's political consciousness found a fertile environment. Her first contact with circles of self-education had come already in late 1883 or early 1884 while she was still in school. ${ }^{24}$ The often illegal circles were a widespread phenomenon during the decade as students sought to obtain a broader, and what seemed to them more politically relevant, education than that available in the gymnasia and universities. It was here that Kuskova had first sampled such forbidden fare as P.L. Lavrov's Historical Letters, a work that would greatly influence the development of her social conscience. ${ }^{25}$

The full dimensions of the world of the radical intelligentsia, however, were revealed to Kuskova only after her marriage to Iuvenaliev. The son of a civil servant and a member of the Saratov gentry, Iuvenaliev had led an illegal student club and had taken part in anti-government demonstrations while studying mathematics at Kiev University. His advocacy of constitutional government for Russia and his continued agitation for popular uprising eventually led to several arrests and a brief period of exile in the late $1870 \mathrm{~s} .{ }^{26}$ Although no longer active in the revolutionary movement by the time he and Kuskova met, Iuvenaliev had not forsaken the cause. He maintained numerous acquaintances among the Saratov radical intelligentsia, including the legendary Chernyshevskii. ${ }^{27}$

${ }^{23}$ Kuskova provides a vivid description of the mood of Russian radicals in this period in "Davno minuvshee", XXXXVII (1956), pp. 163-164. On the revolutionary movement in Saratov during the $1880 \mathrm{~s}$, see Shirokova, Ocherki istorii obshchestvennogo dvizheniia $v$ saratovskoi gubernii, pp. 33-55, passim.

${ }^{24}$ Kuskova, "Davno minuvshee", XXXXV, p. 162, and XXXXIV, p. 142.

${ }^{25}$ Ibid., XXXXV, pp. 158-159, and Kuskova to Vol'skii, 31 July 1949, HIWRP, Volsky Collection, box 5 .

26 A.A. Shilov et al. (eds.), Deiateli revoliutsionnogo dvizheniia v Rossii. Biobibliograficheskii slovar', 4 vols (Moscow, 1927-1934), II, pt. 4 (1932), cols 2109-2110, s.v. "Iuvenaliev, Ivan Petrovich"; and Kuskova, "Davno minuvshee", XXXXV, p. 159. Returning to Saratov in 1879 , Iuvenaliev received a teaching appointment at the gymnasium sometime before December 1881 , despite police concern about his "political unreliability". GASO, f. 1, op. 1, 1879, d. 2919, 1l. 1, 4, 7, 10, 13, 17ob.; and TsGAOR, f. 102, 3 d-vo, 1882 , op. 78 , d. $469,1.2$.

${ }^{27}$ Kuskova, "Davno minuvhsee", XXXXVII, pp. 155, 174-175, and Kuskova to Maklakov, 1 November 1951, HIWRP, Maklakov Collection, box 18. Also see Saratovets [I.I. Mainov], "Saratovskii semidesiatnik", Minuvshee gody, no. 4 (1908), pp. 255, 174. 
Once married, Kuskova no longer had to be concerned with the burdensome duties and financial responsibilities that had previously consumed nearly all of her time. "[L]ife was quiet, without these petty financial distractions", she recalls, "and it was possible to devote myself wholly to intellectual occupations." ${ }^{28}$ Uninterested in a life of domesticity, she now joined Iuvenaliev in organizing a "home university" (domashnyi universitet) where approximately fifteen gymnasium students and graduates would further their academic education. ${ }^{29}$

In this period, Kuskova also attended one of Saratov's main radical circles, the Balmashev circle, which, according to a fellow participant, "all the best part of the Saratov youth of that time entered". ${ }^{30}$ The circle had been organized shortly after V.A. Balmashev's return from political exile in 1884, and under his guidance read and discussed the writings of Russia's critic-publicists from V.G. Belinskii to N.K. Mikhailovskii, the writings of the political economist, N.I. Sieber, along with the standard sociological works of Herbert Spencer and the political tracts of Karl Kautsky. It is very likely this circle that Kuskova is remembering when she writes in her memoirs:

In our catalogues of recommended books (katalogakh dlia chteniia) there were many books on the history of the French Revolution. On the history of Russia there was almost nothing. On the other hand, with the greatest attention we not only read but also studied the works of Ivaniukov, $A$ Short Course on Political Economy [and] his Fundamentals of Political Economics from Adam Smith to Our Day; The Political Economy by Mill with Notes by Chernyshevskii; Schäffle's The Essence of Socialism; Lokhvitskii's Survey of Contemporary Constitutions; and, of course, the first volume of Marx's Capital (though we did not master everything); and then a multitude of pamphlets of German origin: Kautsky, Engels (Anti-Dühring and Origin of the Family, Property and the State), Schippel, Kampffmeyer; articles from the Social Democratic journal Neue Zeit; pamphlets from the French Socialists Guesde, Lafargue, the speeches of Jaurès and so on. Russia, its manners and life entered our heads from belles lettres, especially from the works of Gleb Uspenskii, Korolenko, Karonin and others. ${ }^{31}$

Another of the circle's participants, V.M. Chernov, later to become wellknown as the leader of the Socialist Revolutionary Party, recalls that they also read the novels of the Populist writers, I.V. Omulevskii and D.L. Nordovtsev. ${ }^{32}$ Such undistinguished literature was clearly chosen for its

${ }^{28}$ Kuskova, "Davno minuvshee”, XXXXVII, pp. 162-163.

${ }^{29}$ Ibid., pp. 165-166.

${ }^{30}$ A. Smirnov, "Valerian Aleksandrovich Balmashev", Katorga i ssylka, no. 2/23 (1926), p. 243. Also see Kuskova "Davno minuvshee", XXXXVII, p. 165; and Shilov, Deiateli, II, pt. 1 (1929), col. 78 s.v. "Balmashev, Valerian Aleksandrovich".

${ }^{31}$ Kuskova, "Davno minuvshee", LI (1957), pp. 160-161.

${ }^{32}$ Chernov, Zapiski sotsialista revoliutsionera, p. 34. 
social content rather than its aesthetic qualities. Balmashev also provided back issues of the so-called "thick journals", notably Vestnik evropy (Messenger of Europe) and Otechestvennye zapiski (Notes of the Fatherland). Kuskova remembers how the youths reluctantly followed their mentor's advice to read Chernyshevskii's economic and sociological articles in addition to his famous novel, What Is to Be Done? ${ }^{33}$

Balmashev conscientiously refrained from imposing his own Populist views on the circle's participants, remaining content simply to direct the discussions to urgent and controversial issues. In the words of one member: "For him it was necessary to awaken thought in the youths, to force them to work, to regard their surroundings critically; all the rest was to come by itself. ${ }^{34}$ And Kuskova writes:

In that time, the ' $80 \mathrm{~s}$, in the Balmashev and other circles of this type, there was no direct call to revolution or going to the people [ . . . The whole struggle was directed towards the refutation of the Tolstoian theory of 'nonresistance to evil' and towards criticism of 'apathetic' Russian society that easily yields to reaction.

"In the second half of the eighties, the question about 'the meaning of life' was the theme of the discussions. How to live? What to serve?"3

Kuskova's life during this period was not altogether free of personal difficulties. Only two or three years after her marriage it was discovered that Iuvenaliev was suffering from tuberculosis. This meant that their "home university" had to be curtailed, although Kuskova apparently continued to participate in other circles. ${ }^{36}$ In these years, the family - which by 1887 included a son, Kolia - spent considerable time at the small Iuvenaliev estate in the village of Gubarevka just outside Saratov. In the neighboring village of Viazovka, the estate of Iuvenaliev's friend, S.A. Markovskii, a former narodovolets (member of the People's Will), served as a meeting place for local intelligentsia and visitors from Saratov. Kuskova was soon making regular appearances at the evening gatherings there. Among the radicals whom she met at Markovskii's were another former narodovolets, S.A. Malyshev, the Populist writer N.E. Karonin (Petropavlovskii), and the local zemstvo doctor, A.V. Amsterdamskii. The latter, with whom she

${ }^{33}$ Kuskova, "Davno minuvshee", XXXXVII, pp. 169-170, 173-174. Also see Smirnov, "Valerian Aleksandrovich Balmashev", pp. 242-243.

${ }^{34}$ Smirnov, "Valerian Aleksandrovich Balmashev", p. 243. Also see Chernov, Zapiski sotsialista revoliutsionera, pp. 42-43.

${ }^{35}$ Kuskova, "Davno minuvshee", XXXXVII, p. 165 (her emphasis) and XXXXVIII (1957), p. 140. Also see ibid., XXXXVIII, pp. 159-160. On the importance of the circles of self-education in the radicalization process of future Social Democratic women, see Fieseler, "Women in Russian Social Democracy", pp. 6, 10-11.

${ }^{36}$ Kuskova, "Davno minuvshee", XXXXVII, p. 176, and XXXXVIII, p. 139. 
soon became close friends, was apparently one of the few liberals Kuskova encountered during these years. In contrast to Iuvenaliev, whose constitutionalist views he shared, Amsterdamskii was extremely skeptical about the future of the revolutionary movement. ${ }^{37}$

Unfortunately, Kuskova has written relatively little about the impact upon her of the political ideas she encountered in this period. In the Balmashev circle and probably elsewhere, she had been introduced to the theories of Marx and Engels as well as their European and Russian followers. Despite the importance that Marxist theory was eventually to have for her, however, there is no indication that any aspect of it produced an impression in these years.

As for Populist ideas, still dominant in this period, Kuskova seems to have had a good deal of sympathy with some of these. She clearly shared the Populists' concern for the plight of the peasantry as well as their desire to ameliorate the peasants' condition. ${ }^{38}$ No doubt the social and economic injustices depicted in their novels helped mold her social conscience and nurture in her a dislike for the established order. Yet, Kuskova does not seem to have shared the Populists idealization of "the people" (narod), their glorification of the peasant commune or their vision of a separate path for Russia's economic and social development. And there is nothing to suggest that Populist revolutionism held any particular appeal for her. In her memoirs, Kuskova describes Mikhailovskii as "our genuine "teacher of life' and indeed truly the guide in the matter of 'self-education' ", adding that she "was his faithful and enthusiastic pupil in early youth" ${ }^{39}$ But the influence that Mikhailovskii, like Lavrov, exerted on her derived from his methodological rather than from his political authority. What was important in the thought of both these Populists was not their political ideas but their critical approach. ${ }^{40}$

At the end of the 1880s, Kuskova's political thought was still in embryonic form; ideas, but not yet an ideology. No doubt this was due principally to a cautious temperament and the limits of her experience. Yet, it may also have been the result of a conscious decision - arrived at under the influence of her husband and Balmashev - not to commit herself for the time being to any specific political doctrine. Over the next several years, the ideas and aspirations nurtured in the radical circles of her youth would gradually develop into an ideological orientation.

The turn of the decade brought further tragedy and personal difficulties to Kuskova. Iuvenaliev died at the end of 1889 ; soon afterwards she lost an

${ }^{37}$ Ibid., XXXXVIII, pp. 140, 143-153, passim, and Kuskova to Vol'skii, 31 July 1949, and 14 August 1949, HIWRP, Volsky Collection, box 5.

${ }^{38}$ Kuskova, "Davno minuvshee", XXXXVII, p. 168

${ }^{39}$ Ibid., p. 170.

40 Ibid., p. 168 . 
infant son in a diphtheria epidemic. ${ }^{41}$ Recalling this critical period, she writes:

I was exactly twenty years old, I had a child on my hands and no means. That education which $I$ received in the circles and under the guidance of my husband did not give me any special knowledge. Did it mean that [I must] serve again [. . . ] in the railroad administration? But this time my whole spirit protested against this narrow work. ${ }^{42}$

Clearly a job with the railroad administration could not provide that "meaningful life" that her emerging radical consciousness demanded. Equally limiting were the few alternatives available to a widow with a young child. Thus, Kuskova decided to study medicine, which at least held the prospect of a future of humanitarian service to society. ${ }^{43}$ Even more importantly, such study provided her with an opportunity for further education at a time when women were still excluded from the universities and when most of the "women's higher courses" had been closed. ${ }^{44}$

Because women were not allowed into university medical courses, Kuskova faced the choice of going abroad to become a doctor or remaining in Russia where she could obtain only paramedical training. ${ }^{45}$ She was not particularly eager to go abroad, since it would mean leaving young Kolia behind. She decided, therefore, to go to St. Petersburg for the Rozhdestvenskie Courses that her sister was just completing. There she would study to become a medical assistant (fel'dsher). When it came time to leave for St. Petersburg in the autumn of 1890 , however, Kuskova was informed that all first year places were filled. Thus, she resolved to go instead to Moscow where she could study midwifery (akusherstvo) while awaiting an opening in the Rozhdestvenskie Courses. ${ }^{46}$ For reasons that are not clear, she remained in Saratov for another year, apparently continuing to take part in local radical circles.

${ }^{41}$ Ibid., XXXXVIII, p. 162, XXXXIX (1957), pp. 143, 147-148, and Kuskova to Vol'skii, 14 August 1949.

${ }^{42}$ Kuskova, "Davno minuvshee", XXXXIX, p. 149.

${ }^{43}$ Idealism and a desire to be of service to society had long motivated Russian women to take up the study of medicine. See Barbara Engels, Mothers and Daughters: Women of the Intelligentsia in Nineteenth Century Russia (Cambridge, 1983), pp. 156ff. The appeal that medicine held for radical women is discussed briefly in Robert H. McNeal, "Women in the Russian Radical Movement", Journal of Social History, V (1971-72), pp. 152-153; and Stites, The Women's Liberation Movement in Russia, p. 54.

44 In 1886 the Minister of Education had closed further admission to the "women's higher courses"; by 1889, the St. Petersburg Bestuzhev Courses were all that remained. Satina, Education of Women in Pre-revolutionary Russia, pp. 103, 105-106.

${ }^{45}$ Kuskova, "Davno minuvshee", XXXXIX, p. 149. For an interesting discussion of the medical education then available to women, see Dudgeon, "Women and Higher Education in Russia", pp. 100-104, 141-142, 196, 206.

46 Kuskova, "Davno minuvshee", XXXXIX, p. 150. 
It was probably sometime in late summer of 1891 that Kuskova, now aged twenty-one, finally reached Moscow with her son. After finding lodgings and enrolling in the midwifery courses at the Foundling Home (Vospitatel'nyi dom), she began at once to acquaint herself with the city. ${ }^{47}$ "In the sense of the public movement", she recalls in her memoirs, "in those years Moscow was considered 'God-forsaken', and only the students, almost completely composed of some radicals of indefinite coloring, simmered [burlilo] there." Friends in Saratov had provided her with contacts, among them a young medical student, A.N. Vinokurov, and his wife, who were members of a group that would soon form the core of an important Social Democratic circle. It was not long before Kuskova, too, became an integral part of the city's radical scene. ${ }^{48}$

In 1891, Moscow student circles were still largely circles of self-education. The first student group that Kuskova joined had been formed, like her Saratov circles, "to study, but not to be involved with the public". This circle, which often met in Kuskova's apartment, was composed almost exclusively of men. ${ }^{49}$ While women were able to participate in the radical student circles of this period on an equal, or nearly equal footing with men, ${ }^{50}$ because of the still limited number of women seeking higher education, there were relatively few in a position to do so. Indeed, throughout her student years, Kuskova seems to have been one of the few women in her circles.

It was in this Moscow circle of self-education that Kuskova was introduced to the writings of Kant and Hegel that were to provide the ethical and philosophical underpinnings of her future Marxism. The abstruse constructs of these idealist philosophers were not entirely comprehensible to this group of young dilettantes, however, and she recalls: "As for our reading of Kant and Hegel, [...] there was not a single more or less educated philosopher in our circle. [ . . ] Many years later [ . . ] I was struck by how we 'distorted' Kant." 51

${ }^{47}$ Ibid., pp. 153-154. Kuskova's enrollment in the medical courses was noted by the police. TsGAOR, f. 102, 3 d-vo, 1894, d. 19, 1. 2.

${ }_{48}$ Kuskova, "Davno minuvshee", XXXXIX, p. 154. For a summary of contemporaries' assessments of the revolutionary situation in Moscow at the turn of the decade, see V.I. Nevskii, Ocherki po istorii Rossiiskoi Kommunisticheskoi Partii (2nd ed., Leningrad, 1925), p. 281.

${ }^{49}$ Kuskova, "Davno minuvshee", XXXXIX, p. 154. Little information is available about the members of this circle. Kuskova recalls: "Into this circle went P.M. Troitskii, a science student; Dubrovin; the Greek Kefali; Ural Cossack Cha[l]usov; and G.L. Tiraspol'skii, a student at the higher Moscow Technological School." Ibid.

${ }^{50}$ See McNeal, "Women in the Russian Radical Movement", for what is still one of the best assessments of women's roles and status in radical circles.

${ }^{51}$ Kuskova, "Davno minuvshee", XXXXIX, p. 155. 
In her memoirs, Kuskova states that she did not encounter a single Marxist circle during her first year in Moscow. ${ }^{52}$ Although the influence of Social Democracy was not yet as strong there as it was in St. Petersburg, Marxists had been active in Moscow for nearly a decade. Whether she were aware of it or not, in 1891, a number of students and young intelligentsia were meeting regularly to discuss the writings of Marx and Engels. ${ }^{53}$ Nevertheless, Kuskova's experience reflects the fact that it would be mid-1892 before Russian Social Democrats began to make their presence known beyond their own immediate circles. The famine of 1891-92 was to be the catalyst for this.

During the summer of 1891, Russia suffered the most serious crop failure since the $1830 \mathrm{~s}$, and in its wake came famine. As the famine spread, the conviction developed among "society" (obshchestvo) that the government was not only unwilling but also unable to provide adequate aid to the starving. ${ }^{54}$ Sometime during the winter of 1891-92, the Populist writer, N.M. Astyrev, organized a circle of Moscow literati and students who hoped to use the famine to raise the social and political consciousness of the peasantry. In March 1892, the group decided to begin widespread antigovernment agitation in the countryside. To this end, Astyrev produced his "First Letter to the Starving Peasants" in which he explained to them the connection between the famine and government policies, arguing that the peasantry's only salvation lay in cooperating with the "peasant well-wishers" of the cities in a struggle to overthrow the existing order. ${ }^{55}$

A member of Kuskova's student circle, M. Chalusov, had no difficulty convincing her to help distribute Astyrev's "First Letter" and to copy another revolutionary appeal, P.F. Nikolaev's "Letter of an Old Friend". Kuskova's participation in such activities might seem to indicate Populist inclinations on her part. But in these years she remained, by her own account, "bez polozheniia" - a person without an ideological position. ${ }^{56}$

52 Ibid.

${ }_{53}$ The activities of the Moscow Marxist circles in 1891 and early 1892 are described in A. Vinokurov, "O vozniknovenii moskovskoi partiinoi organizatsii", in Mitskevich, $\mathrm{Na}$ zare rabochego dvizheniia v Moskve, pp. 40-41, editorial note; and M. Liadov [N.M. Mandel'shtam], "Kak zarodilas' moskovskaia rabochaia organizatisiia", in $\mathrm{Na}$ zare rabochego dvizheniia v Moskve, pp. 43ff. Also see Norman M. Naimark, Terrorists and Social Democrats: The Russian Revolutionary Movement under Alexander III (Cambridge, MA, 1983), pp. 175ff.

${ }_{54}$ See Richard G. Robbins, Jr., Famine in Russia, 1891-1892: The Imperial Government Responds to a Crisis (New York, 1975), p. 31 for a discussion of the reality of the situation versus the perceptions of "society" (i.e., the educated, cultured element of the populace as distinct from "the people" (narod)).

${ }_{55}$ Obzor vazhneishikh dozanii, XVII, pt. 1, p. 8; and Men'shchikov, Okhrana i revoliutsiia, I, pp. 130-131, 133, 396. Astyrev's letter is reproduced in G. S[aar], "Muzhitskii dobrokhot", Katorga i ssylka, no. 5/78 (1931), pp. 130-132.

${ }^{56}$ Kuskova, "Davno minuvshee", XXXXIX, p. 155. Also see pp. 155-157, and Kusko- 
Her willingness to assist the Astyrev circle stemmed not from any ideological allegiance to Populism but rather from a desire to protest openly against the existing order and to participate, if only indirectly, in the effort to free Russia from a regime that she, like so many others, held responsible for the famine.

Astyrev's circle was destroyed by the police at the end of March 1892, but aims similar to the circle's continued to motivate Moscow radicals. Sometime during the spring, under the banner of Nikolaev's "Letter of an Old Friend", students began organizing a new group whose ultimate goal was to rouse the bosiaki (déclassé urban elements) in an effort to abolish the autocracy and obtain a constitution for Russia. According to the Populist, Chernov, Kuskova was among those "seized by the general 'infection" " of this bosiaki movement. ${ }^{57}$

At this point, however, motivated both by humanitarian and political concern, Kuskova left Moscow for Saratov to assist in famine relief efforts there. ${ }^{58}$ The famine seemed to her, as it did to "society" in general, to be the result of inept and uncaring governmental policies; as the crisis deepened, so did her conviction that the government was to blame. Participation in famine relief was a way not only to help the starving but also to protest against the indifference of the regime. ${ }^{59}$

The Volga region was one of the areas hardest hit by the famine, and the city to which Kuskova returned in the summer of 1892 was much changed from the one she had left a year before. She quickly discovered the city's revolutionary nexus in the circle of long-time leading Populist, M.A. Natanson. Composed of intelligentsia of every ideological bent - Populists, Marxists and liberals - this circle was extremely critical of the government's handling of famine relief and was already at work forging a union of Saratov's revolutionary and oppositional elements. Kuskova had brought with her from Moscow several copies of Nikolaev's "Letter of an Old Friend", one of which she gave to Natanson. Her contact with this circle was limited, however; police records would later indicate only that she had "associated with a circle of 'unreliables' ("neblagonadezhnye')". ${ }^{60}$

va to L.O. Dan, 29 March 1957, IISG, Dan Archive, packet XVI, folder 13. See, too, Chernov, Zapiski sotsialista revoliutsionera, pp. 157-158. Nikolaev's “Pis'mo starogo druga" is summarized ibid., pp. 149-156.

${ }^{57}$ Chernov, Zapiski sotsialista revoliutsionera, p. 158. Also ibid., pp. 148-149. On the destruction of the Astyrev circle, see Obzor vazhneishikh dozanii, XVII, pt. 1, pp. 8-10; and Mitskevich, Okhrana i revoliutsiia, I, p. 67.

58 Kuskova, "Tragediia Maksima Gor'kogo", p. 231, "Davno minuvshee", XXXXIX, p. 157, and L (1957), pp. 175-176.

${ }_{59}$ Kuskova, "Davno minuvshee”, XXXXIX, pp. 156-158.

${ }^{60}$ Ibid., pp. 158-159, 161, 167, and Kuskova to Vol'skii, 14 August 1949; and TsGAOR,

f. 102,3 d-vo, 1894 , d. 19, 1. 2. See also Chernov, Zapiski sotsialista revoliutsionera, p. 94 . 
Kuskova had apparently just completed training with the public health services when cholera struck Saratov at the beginning of July; soon she was making the rounds of the city to register the sick and dying. As the disease spread, so did suspicions among the populace that medical personnel and other relief workers were the source of this new disaster ${ }^{61}$ Everywhere riots followed in the wake of the epidemic, as frenzied mobs took revenge upon those they thought responsible for their miseries. Caught up in these riots, Kuskova was fortunate to escape with her life. ${ }^{62}$

The experiences of the spring and summer affected Kuskova profoundly. She had at last had an opportunity to act on her radical convictions, and in so doing had come to examine more closely the responsibilities and implications of those convictions. "I already knew", she recalls in her memoirs, "that this pursuit of 'the masses' would not be repeated further: the experiment was too painful. From it a certain capacity developed to investigate social phenomena more deeply and to choose my path more carefully." 63

The famine must have seemed to Kuskova, as it did to many others, a vivid demonstration of the bankruptcy of Russia's autocratic regime. ${ }^{64}$ Indeed, it appears to have convinced her of the need for political as well as social and economic change, and to have fixed in her mind the idea that the abolition of the autocracy had to be the primary goal of all oppositional and revolutionary forces.

Kuskova had never shared the Populists' unbridled faith in the revolutionary potential of the peasantry. However, the failure of the anticipated fusion of the intelligentsia and the masses during the famine persuaded her that the peasants could not be included in any strategy for overthrowing the autocracy. Moreover, the events of the spring and summer had brought into sharp relief the inadequacy of the current revolutionary leadership to direct the attack against the government. Finally, the riots themselves had turned Kuskova irrevocably against the tactics of violence and underscored for her the desirability of peaceful methods of struggle. ${ }^{65}$ So it was that she emerged

${ }^{61}$ Kuskova, "Davno minuvshee", XXXXIX, pp. 161-163. Also see V.A. Obolenskii, Ocherki minuvshego (Belgrade, 1931), pp. 223-224; and Smirnov, "Valerian Aleksandrovich Balmashev", p. 243.

${ }^{62}$ Kuskova, "Davno minuvshee", XXXXIX, pp. 163-167, Kuskova to Vol'skii, 14 August 1949 and 23 May 1957, HIWRP, Volsky Collection, box 5, and Kuskova to Dan, 19 April 1952, IISG, Dan Archive, packet XIII, folder 8. Cf. Chernov, Zapiski sotsialista revoliutsionera, pp. 94-95.

${ }^{63}$ Kuskova, "Davno minuvshee", XXXXIX, p. 167.

${ }^{64}$ Russian radicals and liberals alike were unanimous in perceiving the famine and its consequences as evidence of "the infirmity and unfitness of the autocratic regime". Men'shchikov, Okhrana i revoliutsiia, I, p. 130.

${ }^{65}$ Kuskova, "Davno minuvshee", XXXXIX, p. 167, Kuskova to Volskii, 14 August 1949, Kuskova to Dan, 19 April 1952, Kuskova to Dan, 10 August 1957, IISG, Dan Archive, packet XIV, folder 13, and "Tragediia Maksima Gor'kogo", p. 231. 
from the experiences of the 1891-92 famine in a new frame of mind, more aware both of the problems confronting Russia and of the solutions that would not work.

Shortly after the Saratov riots, Kuskova's apartment was searched by the police, possibly in connection with their investigation of the Astyrev affair. According to the account in her memoirs, although gendarme officials found nothing incriminating, they nevertheless proceeded to expel her from Saratov. She was ordered first to the provincial capital of Penza and then back to Moscow where, because of the inconclusive results of the investigation, she was allowed to return to her medical studies at the Foundling Home. ${ }^{66}$

The Moscow radical scene had changed dramatically during Kuskova's brief absence. The search for an explanation for the tragic events of the famine had provided Russian Social Democrats with their first opportunity to challenge publicly the Populists' analysis of the country's economic development. The question under debate when Kuskova returned to the capital was, in her words, "whether Russia will be capitalist, i.e., whether she will follow the path of the West, or whether a distinctive path of 'peasant socialism' lies ahead for her". ${ }^{67}$ The argument for the former course was now being advanced by Moscow Social Democrats.

During the spring of 1892 , two new Social Democratic circles had emerged among Moscow students and young intelligentsia, both of which were composed predominantly, if not exclusively, of men. One of these circles was led by Kuskova's acquaintance, Vinokurov, and included, among other people, two future prominent Bolsheviks, S.I. Mitskevich and M.N. Liadov. The other circle was headed by a young lawyer, A.I. Riazanov. Among the members of this group were A.I. Davydov, who had converted to Marxism while abroad as a student in the late 1880s, and A.S. Rozanov, soon to become one of the leaders of Social Democracy in Nizhnii Novgorod (now Gor'kii). ${ }^{68}$

${ }^{66}$ Kuskova, "Davno minuvshee”, XXXXIX, pp. 169-170, and L, pp. 173-175. She also mentions her expulsion from Saratov in Kuskova to Vol'skii, 19 August 1949, HIWRP, Volsky Collection, box 5, and Kuskova to Dan, 19 April 1952. This episode is puzzling, since there is no corroborating evidence in the available police files, and elsewhere Kuskova says that she was sent from Penza to Nizhnii Novgorod. "Tragediia Maksima Gor'kogo", p. 231.

${ }^{67}$ Kuskova, "Davno minuvshee", L, p. 182.

${ }^{68}$ S.I. Mitskevich et al., "Pamiati tovarishchei Arkadiia Ivanovicha Riazanova i Evgeniia Ignat'evicha Sponti", Katorga i ssylka, no. 6/79 (1931), p. 182; S.I. Mitskevich, "Na zare rabochego dvizheniia v Moskve", in Na zare rabochego dvizheniia v Moskve, pp. 9-10; Vinokurov, "O vozniknovenii moskovskoi partiinoi organizatsii", pp. 30-33, 37-38; Liadov, "Kak zarodilas' moskovskaia rabochaia organizatsiia", pp. 42, 52-53; A.I. Riazanov, "Vospominaniia", in Mitskevich, Na zare rabochego dvizheniia $v$ Moskve, pp. 132-133; and Mitskevich, Na grani dvukh epokh, pp. 100, 114, 117-118, 121-122. 
Kuskova's new Moscow quarters adjoined those of Riazanov, and she soon found herself in contact with the Social Democrats. Although she states in her memoirs that she became a member of the Riazanov circle, in fact she seems to have belonged to another circle associated with, but not an integral part of, Riazanov's. This peripheral circle was apparently organized in the late summer or early autumn of 1892 and again consisted largely of men. Participants included the law student, P.I. Kuskov; the future prominent liberal politician, A.N. Maksimov; and the young statistician and economist, S.N. Prokopovich ${ }^{69}$ The political orientation of the circle does not appear to have been clearly defined, perhaps intentionally. Prokopovich and Maksimov considered themselves Populists; and while Kuskov did not regard himself as such, in his correspondence with Kuskova he expressed his desire to "go to the people". 70

Given the nature of Kuskov's, Maksimov's and Prokopovich's political views, it seems likely that it was Kuskova who provided the link between their circle and that of her neighbor, Riazanov. The Riazanov circle, like all the early Marxist circles, functioned in two spheres. Privately its members gathered statistical data on Russia's economic development and met to translate foreign (primarily German and French) socialist and Marxist literature they had collected. Publicly, members of the circle took part in student evenings (studencheskie vecherinki) where they attempted to spread their Marxist views through open confrontations with Populists and other opponents. ${ }^{71}$

Kuskova's acquaintance with the internal, private work of the Riazanov circle may have been quite limited. Indeed, her contact with the circle may have come exclusively from the student evenings, some of which were held in her apartment. Here she and her friends listened to and argued with members of the Riazanov circle as well as with occasional visitors from the Vinokurov group. In her memoirs, Kuskova recalls these meetings, which

${ }^{69}$ Kuskova, “Davno minuvshee”, L, pp. 178-179. Kuskova to Dan, 25 July 1957, IISG, Dan Archive, packet XVI, folder 13. Also see Kuskova to Vol'skii, 31 July 1949, and "Nadpol'e i podpol'e marksizma". Several things indicate that Kuskova's was in fact a separate circle. In his reminiscences, Riazanov clearly considers Kuskova and her friends outsiders. "Vospominaniia", p. 134. Other members of his circle do not even mention her. Additionally, while police reports noted Kuskova's association with certain Moscow Marxists, none links her with members of the Riazanov circle. Finally, this interpretation is consistent with the testimony in Chernov, Zapiski sotsialista revoliutsionera, pp. 123124; and V.D. Bonch-Bruevich, "Vospominaniia", in V.D. Bonch-Bruevich, Izbrannye sochineniia, 3 vols (Moscow, 1959-1961), II, p. 189.

${ }^{70}$ Men'shchikov, Okhrana i revoliutsiia, I, p. 116; and Obzor vazhneishkih doznanii, XVII, pt. 1, pp. 85-86.

${ }^{71}$ Chernov, Zapiski sotsialista revoliutsionera, pp. 142-143; Riazanov, "Vospominaniia", pp. 133-134; Vinokurov, "O vozniknovenii moskovskoi partiinoi organizatsii", pp. 32-33; and Mitskevich, Na grani dvukh epokh, pp. 122-123. 
"did not resemble previous circles of self-education. People did not come there at all for self-education [...]"; they "came "to argue', but also persistently worked on their favorite themes." She notes, too, the sense of urgency that now pervaded radical circles, the pressing need everyone felt to make an ideological commitment. ${ }^{72}$

At the student evenings, Kuskova was more directly and more intensively exposed than previously to the Marxist analysis of the development of capitalism. Here members of the Riazanov and Vinokurov circles asserted the inevitability of capitalist development in Russia, and argued for the need to spread Marxist ideas among the country's workers in order to assist them in organizing a socialist party. The Populist Chernov, who sometimes attended these student evenings, remembers how persistent the Social Democrats were in their attempts to convert Kuskova to Marxism and how, under their guidance, she directed her "main attention to 'the analysis of primary social forces' ". ${ }^{73}$

Marxian economic materialism, with its emphasis on class as the basis for all thought and action, had a strong appeal for Kuskova. She found Marx's theories much more logical and comprehensible than anything she had yet encountered:

All these Spencers, Lavrovs, and even Mikhailovskii did not give that conception of the structure of society and the position in it of the toilers that Marx did. Simply, clearly he cut the whole - society - into its component parts, defined the social significance of each of them and besides did this so strikingly according to the example of English life that it was difficult to turn one's back on this iron logic. ${ }^{74}$

Indeed, Social Democracy offered Kuskova both an explanation of the past and a hope for the future.

Preoccupied with Marxism throughout 1892, Kuskova still found time that autumn to assist members of her own circle in efforts to obtain money and backing for an illegal journal. ${ }^{75}$ Then, following a brief hiatus in her activities during the winter of $1892-93$ due to ill health ${ }^{76}$ she entered into a fictitious marriage with Kuskov. Like so many marriages between Russian

72 Kuskova, "Davno minuvshee", L, pp. 178, 180. Also, Kuskova to Dan, 25 July 1957; And Riazanov, "Vospominaniia", pp. 134, 146.

${ }^{73}$ Chernov, Zapiski sotsialista revoliutsionera, pp. 142-143. Also see Mitskevich, $\mathrm{Na}$ grani dvukh epokh, p. 117.

${ }_{74}$ Kuskova, “Davno minuvshee”, L, pp. 181-182.

75 The police became aware of the circle's activities in the winter of 1892-93. TsGAOR, DP, III, 1893, d. 217, 11 45ob, 46. Also see Men'shchikov, Okhrana i revoliutsiia, I, pp. 116, 292-293.

${ }_{76}$ Kuskova's physically demanding practicum at the Foundling Home combined with her impoverished circumstances to aggravate a latent tuberculosis serious enough to hospitalize her for a time. Kuskova, "Davno minuvshee", L, pp. 182-183. 
radicals, this one was apparently arranged for political reasons, connected it seems with Kuskova's efforts to rescue her friend from difficulties with the police. Following the marriage in April 1893, the pair left Moscow for Saratov where they would spend the next four months. ${ }^{77}$

In Saratov, Kuskova now discovered a coalition of revolutionary and oppositional forces known as the People's Right Party (Partiia "Narodnogo prava"), forming under the direction of her old Populist acquaintance, Natanson. ${ }^{78}$ Kuskov apparently joined the new organization, but she did not. Despite the fact that she was "sympathetic to both its aims and its tactics", Kuskova was much too "absorbed in the working out of the Marxist doctrine" to be interested in this coalition of liberal and radical intelligentsia. ${ }^{79}$ Recent developments in Russia seemed to her to confirm the applicability of Marx's theories of economic development. The country's rapid industrialization, the stratification of the peasantry as evidenced by the famine of 1891-92, all followed the scheme he had outlined. Thus, she had found her answer to the question of how Russia's political system could be changed; it would be through the class struggle of the proletariat.

By the time Kuskova returned to Moscow at the end of September 1893, her conversion to Social Democracy was complete. Marxists who encountered her over the next months - among them, V.D. Bonch-Bruevich, later a close friend and collaborator of Lenin - were greatly impressed both by her grasp of Marxist theory and by the depth of her conviction. ${ }^{80}$ Kuskova had found in Marxism her answer to the questions of "how to live" and "what to serve". Not only did this ideology offer her "proof" that Russia's autocratic order was doomed, to be replaced by one more equitable and just, but it showed her how she could participate in this revolutionary process of political, social and economic transformation. In Marxism,

7 Ibid., pp. 186-192. Kuskova's description of the circumstances surrounding the marriage is muddled and inaccurate in many respects, as she confuses events that took place in the spring of 1893 with those of the following spring. Okhrana records indicate that Kuskov had been arrested in November of 1892 and released under police surveillance by January 1893. GASO, f. 53, op. 1, 1893, d. 4, 1. 19; Obzor vazhneishikh doznanii, XVII, pt. 2, pp. 41-42, and pt. 1, pp. 85-86, 299; and Men'shchikov, Okhrana i revoliutsiia, I, pp. 292, 419.

${ }^{78}$ Kuskova's change of residence was reported by the police. GASO, f. 53, op. 1, 1893 , d. 4, 1. 14. On the People's Right Party, see Shirokova, Partiia "Narodogo prava".

${ }^{79}$ Kuskova, "Davno minuvshee", L, p. 185. There is no evidence to support the assertion of several historians that Kuskova joined the People's Right Party. V. Akimov [Makhnovets], Ocherk razvitiia sotsialdemokratii v Rossii (St. Petersburg, 1906), p. 51, note; Liadov, Kak nachala skladyvat'sia rossiiskaia kommunisticheskaia partiia, p. 251; V.I. Nevskii, Istoriia RKP (b). Kratkii ocherk (Leningrad, 1926), p. 89; and Galai, The Liberation Movement in Russia, p. 61, are among those who make this claim.

${ }^{80}$ Private communication from Shirokova, who has examined manuscripts of the memoirs of Bonch-Bruevich and other Moscow Marxists. Kuskova's return to Moscow was recorded by the police. GASO, f. 53 , op. 1, 1893, d. 4, 1. 108. 
Kuskova had discovered an ideology that satisfied her and that, albeit with some significant revisions, would remain part of her world view for the rest of her life.

It has been suggested that "what brought many women to radicalism was largely a personal need to prove their worth and independence". ${ }^{81}$ In Kuskova's case, family circumstances had forced a great deal of responsibility upon her at an early age. As a consequence, she had developed considerable self-reliance and a strong sense of self-worth even before turning to radicalism. Yet, participation in the revolutionary movement clearly reinforced her independence and confirmed her self-esteem by giving her life direction and a clear purpose.

Like so many other young women seeking to escape the limited, subordinate position that patriarchal Russian society defined for them, Kuskova was attracted to radicalism both by its promise of a stimulating and rewarding life, and by the opportunity to extend her sphere of activity beyond the narrow confines of the traditional woman's world. She sought out radical circles in an effort to obtain an intellectually richer and more relevant education than that available in a gymnasium that prepared girls only for marriage or life as a spinster teacher. The ideas to which she was exposed in radical circles in turn introduced her to a larger world than the one she had known, a world that pointed the way to "the meaning of life". Commitment to radicalism, and eventually to Marxism, offered her something more fulfilling than her role as wife, mother or midwife; it offered her an opportunity for political action directed at the transformation of society. ${ }^{82}$

One student of Russian Social Democracy has recently observed that Russia's women radicals were attracted to the Marxist movement more for egocentric and emotional reasons than for ideological ones, often becoming Social Democrats rather than Socialist Revolutionaries largely by chance. ${ }^{83}$ This was not true of Kuskova. The Social Democratic movement certainly met many of her emotional needs, ${ }^{84}$ but it was principally ideological

${ }^{81}$ Amy Knight, "The 'Fritschi': A Study of Female Radicals in the Russian Populist Movement", Canadian-American Slavic Studies IX (1975), p. 17.

${ }^{82}$ It is revealing of Kuskova's attitude about traditional women's roles that in her memoirs she discusses her roles as wife and mother only in so far as they affected her political development. Social Democracy's attraction for women as an escape from traditional roles is noted in Fieseler, "Women in Russian Social Democracy", pp. 15-16, 18.

${ }^{83}$ Ibid., pp. 11-13, 18 .

${ }^{84}$ In addition to what has already been mentioned, it is not too much to assume that the Social Democratic movement also served as something of a surrogate family for Kuskova. Fieseler has observed that, for many women who grew up in incomplete families and without what might be considered a "normal" childhood, Social Democracy functioned "as a spiritual home or as a social milieu that could replace what these women had lost or had never had". Ibid., p. 16. 
conviction that drew her to Marxism. Her conversion to Social Democracy came out of a lengthy process of intellectual development and was the result of a carefully considered decision. Having refused for some time to commit herself to any specific ideological position, she embraced Social Democracy only after thoroughly familiarizing herself with Marxist theory and convincing herself of its viability as a revolutionary doctrine.

Even after Kuskova broke with organized Social Democracy at the end of the $1890 \mathrm{~s},{ }^{85}$ she would retain both the analytical method and elements of the revolutionary theory that Marxism provided her as a means of identifying Russia's problems and defining their solutions. Her work in the radicalliberal Union of Liberation (Soiuz osvobozhdeniia) during 1903-05, in the consumer cooperative movement, in the women's movement, and with the Provisional Government during 1917, as well as her journalistic efforts in emigration after 1922, would all reveal Kuskova's continuing commitment to Russia's working class and its struggle for political, economic and social democracy.

${ }^{85}$ Regarding Kuskova's departure from the Social Democratic movement, see Barbara T. Norton, "Eshche raz ekonomizm: E.D. Kuskova, S.N. Prokopovich and the Challenge to Russian Social Democracy", The Russian Review, XXXXV (1986), pp. 183207. It is worth noting in this connection that the role Kuskova was expected to play as a woman in the movement differed significantly from that expected of men. (See Fieseler, "Women in Russian Social Democracy", p. 18 for a discussion of the disparity.) These differing expectations undoubtedly contributed to Kuskova's break with organized Marxism, an issue not adequately explored in Norton, "Eshche raz ekonomizm". 